\title{
Halka Açık ve Halka Açık Olmayan İşletmeler Yönüyle Tekdüzen Muhasebe Sistemi ve Altman Z Skor Modellerinin Uygulanabilirliği
}

\author{
Turkish Uniform Accounting System and Applicability of Altman Z Score Models in the \\ Context of Public and Private Companies
}

Fevzi Serkan ÖZDEMiR ${ }^{1}$

\begin{abstract}
ÖZET
Türkiye'de tekdüzen muhasebe sistemi (TDMS) geliştirme yönündeki çalışmaların 40 yılın üzerinde bir geçmişi vardır. Kıta Avrupası geleneğine uygun olarak vergi düzenlemelerinin etkisi altında şekillendirilmiş olan bu sistem, niteliği bakımından halka açık olsun-olmasın, banka, sigorta şirketleri gibi finansal kuruluşlar hariç her işletmede, halen, en azından yasal bildirimlerin ekinde sunulmak üzere hazırlanan finansal tablolara temel teşkil etmektedir. TDMS'nin günümüz itibariyle yalnızca vergi matrahının doğru belirlenmesine hizmet ettiği görüşü ağırlık kazanmış olsa da, bu sistemin üretilen finansal bilginin kalitesi bakımından daha güçlü bir alternatifinin bulunmadığı dönemde, işletmeye dair karar verecek olanların yapılandırdıkları kararlara ışık tutan tek zorunlu paradigma olduğu unutulmamalıdır. Ayrıca günümüz açısından bakıldığında, halka açık işletmeler için uluslararası finansal raporlama standartlarını temel alan, zorunlu ikincil bir raporlama sistemi, bu işletmelere dair karar verecek olanların bilgi ihtiyaçlarına daha uygun bir raporlama zemini hazırlamış olsa da, halka açık olmayan işletmeler için TDMS tek anahtar olma rolünü sürdürmektedir. Bu durum halka açık olan ve olmayan işletmeleri kıyaslama noktasında TDMS'yi önemli kılarken, Altman Z Skor gibi halka açık olmayan işletmeler için geliştirilmiş olan modellerin de ampirik olarak sınanabilmesinin tek yolu olmaktadır. Bu çalışmanın amacı da TDMS'ye dayalı finansal veriler altında Altman Z, Z've Z" Skor modellerinden hem halka açık olan hem de halka açık olmayan işletmeler yönüyle başvurulabilir olan Z' ve Z" Skor modellerinin, Türkiye için uygulanabilirliklerinin ampirik olarak değerlendirilmesidir.
\end{abstract}

Anahtar Sözcükler: Tekdüzen muhasebe sistemi, halka açık işletme, halka açık olmayan işletme, Altman Z modelleri, finansal başarısızlık.

\section{GíRiş}

Finansal başarısızlık (financial distress) kavramı, sadece finansal sıkıntı içine düşmüş ve bu sıkıntılarından kurtulamayarak iflas (bankruptcy) noktasına gelmiş işletmelerin içinde bulundukları finansal durumu değil, borçlarını ödeyebilme gücünü kaybederek, altına girmiş oldukları yükümlülükleri yerine getiremeyen (default) işletmeleri' de ifade edecek biçimde kul-

\begin{abstract}
The background of the uniform accounting system (UAS) in Turkey is over forty-years. This system, which has been formed under the influence of tax regulations in accordance with Continental Europe customs, is still considered as a basis for statutory financial statements and filings in all companies except for financial institutes such as banks, insurers, etc. whether they are public or private. Even though the idea of that the mission of UAS is only determining the tax base of firms' has been becoming strong recently, it should not be missed out that there was not any other powerful alternative in terms of the quality of financial information and it is the just one compulsory paradigm useful for financial decision makers. Currently, however existed compulsory secondary reporting regime, which based on international financial reporting standards, for public companies has provide a more convenient reporting basis for financial information requirements for decision makers, UAS has been perpetuating its' role of the being only key driver for private companies. This condition not only makes UAS essential for comparing public companies with private ones, but also gives an opportunity to examine the models for private companies like Altman Z Scores. The aim of this empirical study is evaluating applicability of Altman Z' and Z" score models for both Turkish public and private companies of which reports their financial statements based on UAS.
\end{abstract}

Keywords: Turkish uniform accounting system, public companies, private companies, Altman Z models, financial distress.

lanılmaktadır. Iflas, başarısızlık ölçeğinde son noktayı ifadeyi ederken, yükümlülüklerini yerine getirememe hali, iflasa uzanan yolun başlangıcı gibidir. Fakat bir işletme için ne iflas ne de yükümlülüklerini yerine getirememe hali arzu edilen bir durumdur. Bu nedenle işletmelerin başarısızlığa uğramadan önce belirlenmesi, başarısızlıklarına neden olan faktörlerin araştırılması ve yapılacak müdahalelerle devamlılıklarının yeniden sağlanması üzerinde durulması gereken bir 
durum olarak ortaya çıkmaktadır. Nitekim bu amaç doğrultusunda finans bilim adamları, 1960'lardan bu yana yoğun olarak tahmin modelleri üzerinde durmaktadırlar.

Finansal başarısızlık tahmin modellerinin temel özelliği, işletmelerin finansal tablo verilerine dayalı olarak hesaplanan rasyoların girdi olarak kullanılmasıdır. Finansal başarısızlığı ortaya koyan, işletmelerin finansal tabloları olurken; modellerin çıktısı, önsel olarak yapılan başarısızıık tanımı karşısında başarılı ve başarısız olarak ayrıştııılan işletme gruplarıdır.

Türkiye'de özel kanunlarla kurulmuş ve özel muhasebe organizasyonlarına sahip işletmeler (bankalar, sigorta şirketleri, faktöring şirketleri vb.) dışında kalan, ölçekleri ne olursa olsun, her işletme 01.01.1994 yılından beri TDMS'ye göre raporlama yapmakla mükelleftir. Bu mükellefiyet hisse senetleri borsada işlem gören halka açık işletmeler için de geçerlidir. Yani günümüz uygulamasında TDMS, her işletme için yasal bildirimlerin (vergi beyanlarının) dayanağı olma özelliğini korumaktadır. İşletmeler de her mali dönemin sonunda, beyanname eklerinde TDMS'ye göre hazırladıkları finansal tabloları bildirmek zorundadırlar.

TDMS'ye göre düzenlenen finansal tabloların işletmelerin gerçek durumunu ne ölçüde yansıttığı ayrı bir tartışma konusu olsa da, cari mevzuata uygun ve doğruları yansıttıkları ifade edilebilir. Başka bir ifadeyle TDMS'ye dayalı finansal tabloların yeterliliği noktasında küçük işletmelerin durumu ne ise büyük işletmelerin durumu da aynıdır. Halka açık olmayan işletmelerin durumu ne ise, halka açık işletmelerin de durumu aynıdır. Nitekim çalışma ile ortaya konulmak istenen de, TDMS'ye dayalı finansal verileri kullanmak suretiyle, halka açık olan ve halka açık olmayan işletmeler için Altman Z' ve Z" Skor modellerinin uygulanabilirliğini değerlendirmektir. Bu suretle ilk olarak halka açık olan ve olmayan işletme grupları bazında ayrı ayrı olmak üzere, modellerin fiili durumdaki başarılı/başarısız olma halini tahmin başarımları ile başarısız olarak gruplandırdıkları gözlemlerin birbirleri ile uyumluluğuna bakılmıştır. İkinci olarak da ünlü Finans Profesörü Edward Altman tarafından geliştirilmiş Z' ve Z" Skor modellerinin, Türkiye gibi gelişmekte olan bir ekonomide faaliyet gösteren halka açık olan ve olmayan işletmeler yönüyle, geçerli niceliksel bir farklılık sağlayıp sağlamadığı TDMS'ye dayalı finansal veriler yardımıyla değerlendirilmiş̧tir.

\section{TEKDÜZEN MUHASEBE SISTEMI KAVRAMI VE TÜRKIYE'DEKI SISTEM}

\subsection{Muhasebe Kuramında Tekdüzen Muhasebe Sistemi}

Tekdüzen muhasebe sistemi bir kavram olarak, ilk defa 15-16 Aralık 1880 tarihinde yapılan Fransız Muhasebeciler Kongresi'nde ele alınmasına karşın, bir uygulama olarak ilk defa Almanya'da hayata geçirilmiştir (Koç Yalkın, 1972:981). Yeknesak muhasebe, üniform muhasebe, muhasebenin normalizasyonu ve muhasebenin standartlaştırılması kavramlarıyla eş anlamlı kullanılan TDMS'de amaç; muhasebe sisteminin normlaştırılmasıdır (Kartal, 2005: 229). Bir kavram olarak TDMS, belli ölçülerde benzer olan işletmelerin, benzer olaylar ve koşullar karşısında uygulayabilecekleri muhasebe sistemine verilen addır (Koç Yalkın, 1988: 48). TDMS, kapsam ve uygulama düzeyi bakımından sınıflandırılmaktadır.

Kapsamlarına göre TDMS türleri; kısmi, toplu ve geniş kapsamlı olarak sınıflandırılırken, uygulama düzeyi bakımından; işletme, sektör, ulus ve uluslararası düzeyde olmak üzere dörtlü bir sınıflandırma yapılmaktadır². Kapsam ve uygulama düzeyi bakımından hangi nitelikte olursa olsun TDMS geliştirme yönündeki çabaların nedenlerine bakıldığında; amacın her işletme için hem şekil, hem de içerik bakımından tekdüzenin sağlanması olduğu görülmektedir.

TDMS; hükümetler ya da düzenleyici kuruluşlar tarafından yönetsel bir kontrol aracı olarak geliştirilirler. Gerek planlamacılar, gerek vergi otoritesi, hatta yöneticiler için her türlü işletmenin kontrol altında tutulması amacıyla başvurulan TDMS'nin işlevi, muhasebe bilgilerinin kullanımını kolaylaştırmaktır (Choi ve Meek, 2008:42).

Şekil bakımından tekdüzen, biçimi önceden belirlenmiş finansal tablolar yardımı ile sağlanmaktadır. İçerik bakımından tekdüzen ise; muhasebe sisteminin temelini teşkil eden temel kavramlar, muhasebe ilkeleri, rapor sistemi, hesap planı ve terminolojide sağlanan benzerlikler ile mümkün olmaktadır (Koç Yalkın, 1988:48).

Tekdüzeliğin sağlandığı bir muhasebe sisteminden beklenen yararlar ise şunlardır (Hiçşaşmaz, 1970:182):

1. İşletme yönetimine ilişkin sorunların sağlam esaslara dayandırılmış olması,

2. İşletmelerden belli bir düzen içinde toplanan muhasebe verilerinden hareketle yapılacak bilimsel araştırmaların kolaylaşması,

3. Sektörlere ilişkin faaliyet sonuçları hakkında 
edinilecek sistemli bilgilere dayanarak, milli ekonominin sevk ve idaresinde isabetli karar alma imkânının elde edilmesi.

TDMS'nden beklenilen bu yararların gerçekleşebilmesi; biçimi önceden belirlenmiş finansal tablolar ile şekil bakımından; temel kavramlar, muhasebe ilkeleri, rapor sistemi, hesap planı ve terminolojide sağlanacak benzerlikler yönüyle de içerik bakımından, tekdüzeliğin sağlanmış olmasına bağlıdır.

\subsection{Türkiye'de Tekdüzen Muhasebe Sisteminin Tesisi}

Türkiye'de TDMS, ilk defa 1972 yılında uygulanmaya başlamıştır. Uygulamanın amacı, bankacılık ve sigortacılık gibi özel muhasebe organizasyonu gerektiren işletmeler dışında kalan tüm işletmelerde yalnızca finansal muhasebe alanında tekdüzenin sağlanmasıdır. Bu nedenle uygulanmaya başlanılan bu sistemin kapsam bakımından kısmi tekdüzen niteliğinde olduğu kabul edilir. Diğer bir ifadeyle maliyet muhasebesi uygulaması bakımından işletmeler serbesttirler.

Tekdüzene geçiş açısından kısmi TDMS önemli bir aşama olarak görülse de, maliyet muhasebesi uygulamalarını kapsamaması yönüyle yeterli değildir. Türkiye'deki uygulamada da bu eksikliğin ve uygulamada karşılaşılan güçlüklerin giderilmesi amacıyla 1974 yılında yeni bir komisyon oluşturulmuştur.1976 yılında çalışmalarını tamamlayan bu komisyon, maliyet ve yönetim muhasebesinin de ötesinde geniş kapsamlı tekdüzenin öngörüldüğü yeni bir sistemi tesis etmişlerdir. Bazı kaynaklarda, Türkiye'de TDMS'nin 1972 ve 1977 yıllarında kademeli olarak uygulamaya geçirildiği yönündeki bilgilerin nedeni de budur ${ }^{3}$.

\subsection{Türkiye'de Geçerli Tekdüzen Muhasebe Sistemi}

Türkiye'de günümüzde de geçerliliğini koruyan TDMS, Maliye Bakanlığı'nca 213 sayılı Vergi Usul Kanunu'nun 175 ve 257 'nci maddeleri uyarınca hazırlanmış bir tebliğ ekinde düzenlenmiştir. Söz konusu tebliğ, 26 Aralık 1992 tarih ve mükerrer 21447 sayılı Resmi Gazete'de yayımlanırken, 1 Ocak 1994 tarihinden itibaren yürürlüğe girmiştir. Ayrıca Maliye Bakanlığı tarafından 1992 yılı sonunda hazırlanan bu tebliğ, daha sonra çeşitli tarihlerde çıkarılan on dört ilave tebliğ ile geliştirilmiştir. Yayınlanan ilk Tebliğ, 1 nolu MSUGT adı ile anılmaya başlanırken, diğer tebliğler de yayın sırasına göre numaralandırılmıştır. Özetle, bugün itibariyle TDMS'yi tesis etmek üzere yayımlanmış MSUGT sayısı 15'e ulaşmıştır (Özdemir, 2011a:151-152).

Bir bütün olarak sistemin amacl; Türkiye'de bilanço usulüne göre defter tutan işletmelerin varlık ve kaynak bileşimleri üzerinde değişime neden olan işlemlerin, GKGMi'ye göre kaydedilerek, güvenilir bilgi üretilmesini ve bu bilgilerin tutarlı finansal tablolar aracılığı ile raporlanmasıdır (Akdoğan ve Sevilengül, 2007:3).

\subsection{Türkiye'deki TDMS'nin Özellikleri ve Yöneltilen Eleştiriler}

Türkiye'de halen geçerliliğini sürdüren bu sistem, yalnızca finansal muhasebede değil, maliyet muhasebesinde de tekdüzeni öngördüğünden, kapsam bakımından toplu kabul edilirken, uygulama düzeyi bakımından ulusal niteliktedir. Raporlanan bilginin niteliği (kalitesi) bakımından, daha güçlü bir alternatifin uygulanmadığı dönemlerde (1994-2001), TDMS, ihtiyaca uygunluk bakımından tüm işletmeler için yeterli görülmüşse de, özellikle kamuya hesap verme yükümlülüğü bulunan işletmeler yönüyle zamanla ihtiyacı karşılamada sistemin yetersiz olduğu anlaşılmıştır. Nitekim Türkiye'deki TDMS, muhasebenin gelişiminde Kıta Avrupası ülkelerinin göreli hâkimiyetinin bir sonucu olarak, vergi düzenlemelerinin etkisinde şekillenmiştir. Fakat TDMS'ye göre gerçekleştirilen muhasebe uygulamalarının mali mevzuatı esas alması ve mali mevzuatın gerektirdiği biçimde çeşitli uyarlamalara tabi tutularak, vergi beyannamesi ekinde sunulan finansal tablolar formuna sokulması, TDMS'ye göre üretilen finansal tabloların ihtiyaca uygunluğunu sınırlamıştır. Bu durum karşısında ilk olarak kamuya hesap verme yükümlülüğü bulunan işletmeler yönüyle ikincil bir raporlamaya gidilmiştir. Bu durum TDMS'nin günümüzde yalnızca yasal (vergisel) bildirim amacıyla yürütülür hale gelmesinin de başlıca nedeni olmuştur.

\section{FINANSALBAŞARISIZLIKVEALTMAN'IN TAHMIN MODELLERI}

\subsection{Finansal Başarısızlığa İlişkin Literatür}

Finansal başarısızlık literatüründe başarısızlık, sadece iflas biçiminde değil, finansal sıkıntı içine düşmüş olma hali ile de anılmaktadır. Zira finansal başarısızlığın tahmin edilmesinin yararı da iflastan ziyade henüz finansal sıkıntı içine düşmüş işletmelerin belirlenmesi ve alınacak önlemler ile bu işletmelerin iflastan ve içinde bulundukları likidite sıkıntısından çıkarılabilmeleridir.

Literatürde finansal sıkıntı içinde olma hali; işletme faaliyetlerinden elde edilen nakit akışları ile kısa dönemdeki borçların karşılanamaması, kısa dönemdeki taahhütlerin yerine getirilememesi ve işletmenin bu sıkıntıyı aşmak için bazı önlemler almaya zorlanması durumu biçiminde tanımlanmaktadır (Ross, Westerfield ve Jaffe, 2005:832). 
Finansal sıkıntı içine düşmüş işletmelerin yeniden sağlam bir finansal yapıya kavuşturulabilmeleri için bu işletmelerin önceden tespit edilmesi gerekmektedir. Zira finansal başarısızlık, henüz işletmelerin finansal sıkıntı içine düştükleri andan itibaren çeşitli tahmin modelleri yardımı ile önceden belirlenebilmektedir. Özellikle banka, sigorta gibi finansal kuruluşların finansal başarısızlığının ülke ekonomisine daha fazla zarar vereceği endişesi ile bilhassa bu sektörlerdeki şirketlerin finansal başarısızlığının önceden tespitine yönelik modeller daha yaygın olarak kullanılmaktadır. Benzer şekilde işletme yöneticileri ve düzenleyici kuruluşlar da (menkul kıymet borsası, aracı kurumlar, vb.) finansal sıkıntı içine düşen işletmeleri, geliştirdikleri erken uyarı modelleri yardımı ile gözlemekte ve verecekleri ekonomik kararları biçimlendirebilmektedir.

Finansal başarısızlık tahmin modelleri, genellikle başarısızığı istatistiksel olarak tahmin etmeye yönelen modellerdir. İstatistiksel modeller, finansal başarısızlık olayını, karar vericinin öznel yorumu ile değil; nesnel bir biçimde belirlemeye imkân verir. Modellerin tahmin gücünü ise, analizde kullanılan nesnel verilerin finansal başarısızlığı yansıtabilme gücü belirler (Aktaş, 1997:24-25).

Finansal başarısızlık tahmin modellerine ilişkin literatür incelendiğinde; tahmin modellerinin içerdiği bağımsız değişken sayısına göre; modellerin tek değişkenli ve çok değişkenli modeller biçiminde ikiye ayrıldığı görülmektedir.

Finansal başarısızlık tahminlerinde kullanılan tek değişkenli modeller, çeşitli finansal oranları ayrı ayrı ele alarak, işletmelerin finansal başarısızlık risklerini belirlemeye yönelen modellerdir. Tek değişkenli modellere, literatürde statik modeller de denilmektedir (Aktaş, 1997: 26; Keskin, 2002: 28). Bu modellerin özelliği, incelenen işletmelerin performansını, tek bir bağımsız değişken ile açıklamasıdır. Bu modeller arasında öne çıkanlar; basit ikili regresyon, tekli diskriminant ve Markov Zinciriyöntemine dayalı modellerdir (Keskin, 2002: 28; Doğrul, 2009:56; Yılgör vd., 2011:330).

Modellerde açıklayıcı değişken olarak yer alan finansal oranlar, işletmelerin gelecekteki performanslarını belirlemek üzere, işletmelerin kredi değerliliği yönüyle ilk defa 1849 yılında çalışmalara konu olmuştur. 1930'lu yıllar ile birlikte de bu çalışmalar hız kazanmış, nihayet çok boyutlu tahmin modellerinin gelişmesinde de mihenk taşı olmuşlardır (Altman, 1968, 590; Keskin, 2002:29).

Tek değişkenli model ile finansal başarısızlık tahmininde bulunulan ilk çalışma ise 1935 yılında yapıl- mıştır. 133 işletme ile gerçekleştirilen bu çalışmada net işletme sermayesi oranı işletmelerin başarısızlık durumlarının tespit edilmesinde en önemli oransal değişken olarak belirlenmiştir. Ayrıca toplam varlıkların toplam borçlara oranı ve toplam varlıkların sabit varlıklara oranı, yine aynı çalışmada önemli diğer oransal değişkenler olarak belirlenmiştir (Aktaş, 1997:27).

Tek değişkenli finansal başarısızlık tahmin modellerini kullanan ve adından en çok söz ettiren çalışma ise Beaver'in 1954 ve 1964 yılları arasında, finansal başarısızlığa uğramış 79 işletme ile başarılı olarak belirlenen 79 işletmeyi kapsayan araştırması olmuştur. Beaver (1966)'e göre finansal başarısızlık; vadesi gelen finansal yükümlülükleri ödeyememektir. Ona göre iflas, tahvil faizlerinin ödenememesi, karşılıksız çek yazılması, imtiyazlı hisse senetlerine temettü dağıtılmaması bu duruma neden olabilecek olaylardandır.

Beaver (1966) ilk olarak eşleştirmeli örnekleme yöntemini kullanarak, başarısız ve başarılı olarak ayrıştırdığı grupların, çeşitli finansal oranlarının ortalamalarını karşılaştırmış ve finansal olarak başarısız kabul ettiği işletmelerin finansal oranlarının başarılı işletmelere göre daha iyi olmadığı sonucuna ulaşmıştır.

Tek değişkenli modeller ile finansal başarısızlık tahminlerinde bulunmanın üstün yanı, bu modellerin uygulanması ve modellerin sonuçlarının yorumlanmasının kolaylığıdır. Buna karşın tek değişkenli modeller yardımıyla elde edilen bulgular, yanıltıcı olabilmesi yönüyle de eleştiri konusu edilmişlerdir. Şöyle ki, seçilen finansal oran bakımından işletmenin performansı değerlendirilmiş ve işletmenin başarııı olduğu belirlenmiş iken, farklı bir oran yönüyle aynı işletmenin başarısız olarak belirlenmesi bir çelişki olarak görülmüştür. Ayrıca çok değişkenli bir modele dâhil edildiğinde, modelin açıklama gücünü artıran bir değişkenin, tek değişkenli modeller de anlamsız sonuçlar vermesi de eleştiriler arasında sıralanmıştır. Nitekim tek değişkenli finansal başarısızlık tahmin modelleri, çok değişkenli modellerin başarısızlık tahminlerinde kullanılmaya başlamasının ardından başvurulan modeller olmaktan çıkmıştır. Tek değişkenli modeller, sonradan yöneltilen eleştirilere rağmen, finansal başarısızık tahmin literatürünün gelişiminde en eski ve temel çalışmalar olmaları bakımından önemini korumaktadır.

Çok değişkenli modeller yardımıyla finansal başarısızlık tahmini ise ilk defa Altman (1968) tarafından gerçekleştirilmiştir. Altman (1968) tarafından yapılan ilk çok değişkenli finansal başarısızık tahmin çalışmaSı, birçok araştırmacıyı, finansal başarısızlıkların önceden tahmin edilebilmesine yönelik modeller geliştir- 
me, geliştirilmiş modellere yönelik eleştiriler getirme veya farklı modellere yönelik karşılaştırmalar yapmak suretiyle çalışmalarda bulunmaya itmiştir.

Finansal başarısızlık tahminlerinde kullanılan çok değişkenli modeller; diskriminant modelleri, regresyon modelleri ve diğer modeller olmak üzere üç gruba ayrılabilir. Bu şekilde bir ayrıma gidilmesinin nedeni, literatürdeki çalışmaların büyük çoğunluğunda, diskriminant ve regresyon modellerinin ayrı ayrı veya birbiri ile karşılaştırmalı olarak yer almış olmasıdır. Diğer modeller ise, finansal başarısızlık tahminlerine yönelik görece daha yeni çalışmalarda başvurulan ve farklı algoritmaları olan modellerdir (Özdemir, 2011b:115).

Diskiriminant modellerinin finansal başarısızlık tahmin literatüründeki yeri oldukça geniştir. Buna diğer araştırmacıların Altman (1968) tarafından geliştirilen doğrusal diskriminant modeline alternatif bir model arayışlarının neden olduğu söylenebilir.

Altman (1968) ilk modelinde, finansal başarısızlığı yasal olarak iflas başvurusunda bulunmuş olma ve kayyum atanmış ya da ulusal iflas yasası hükümlerince reorganizasyon hakkı verilmiş olma biçiminde tanımlamıştır. Altman'ın tanımındaki "yasal olarak iflas başvurusunda bulunmuş olma" Elam (1975), Ohlson (1980), Zavgren (1982), Zmijewski (1983) ve Casey ve Bartczak (1985) gibi önemli yazarlar tarafından da finansal başarısızlık kriteri olarak kabul edilmiştir. Buna karşın birçok yazar finansal başarısızlığı iflas olarak değil, finansal sıkıntı içine düşme hali olarak nitelendirmeye başlamışlardır. Örneğin Wilcox (1970), Edminister (1972), Blum (1974), Deakin (1976) ilk defa finansal başarısızlık tanımını esneten önemli yazarlar olmuşlardır.

Türkçe literatürde de finansal başarısızlık tahminleri konusunda önemli çalışmalar bulunmaktadır. Türkiye'de bu konuda isimleri öne çıkan yazarlar Göktan (1981) ve Aktaş (1991; 1993)'dir. Ayrıca Keskin (2002), Kurtaran Çelik (2009), Doğrul (2009), Özdemir (2011a), Özdemir ve diğerleri(2012), Yılgör ve diğerleri, (2011) tarafından yapılan görece yeni çalışmalarda Türkçe literatürde hemen erişilen eserler arasına girmiştir.

Finansal başarısızık tahminlerine ilişkin gerek yabancı, gerek yerli literatürdeki bu eserlerin ortak özelliği dikkate aldıkları gözlemlerin görece büyük ölçekli işletmeler olması ya da halka açık işletmelerden oluşmasıdır. Nitekim Altman ve Diğerleri (2010), KOBi ölçeğindeki işletmelerin başarısızlık oranlarını izlemenin zorluğuna işaret etmektedir. Bu çalışmaların görece az olmasının bir diğer önemli nedeni de KOBi ölçeğindeki işletmeler ile halka açık olmayan işletme- lerin tabi oldukları finansal raporlama gerekliliklerinin farklı olmasıdır. Şöyle ki, büyük ölçekli veya halka açık işletmeler daha geniş bir bilgi kullanıcısı çevresine sahiptirler ve bu işletmelerin finansal tablolarının kamuya zorunlu olarak veya kendi gönüllü kamuyu aydınlatma politikaları çerçevesinde yayınlanması söz konusu olabilirken, KOBi ölçeğindeki işletmeler ile halka açık olmayan işletmeler için bu türden bir gereklilik bulunmamaktadır.

\subsection{Altman'ın Finansal Başarısızlık Tahmin} Modelleri

Altman (1968) tarafından geliştirilen ve çoklu doğrusal diskriminant tabanlı orijinal Z Skor modeli, geliştirilen ilk çok değişkenli finansal başarısızlık tahmin modeli olarak nitelendirilmektedir (Bemmann, 2005:69). Bu modellerin özelliği; içerdiği her bir oransal değişken ile işletmelerin başarısızlık olasılıkları arasında lineer bir ilişki bulunduğunu varsaymasıdır (Miller, 2009:4).

Doğrusal diskriminant modellerinin genel yapısı aşağıdaki gibidir:

$$
Z_{i}=\beta_{0}+\sum_{j=1}^{m} \beta_{i} \cdot X_{i j}
$$

$j=\{1,2,3, \ldots, m\}$ bağımsız değişken sayısı

$Z_{i}$ : i nci gözlem biriminin diskriminant skoru

$\beta_{j}$ j jnci bağımsız değişkenin diskriminant katsayısı

$X_{\text {i: }}$ i nci gözlem biriminin j nci bağımsız (oransal) değişken değeri

Doğrusal diskriminant modeli, açık bir fonksiyon biçiminde de gösterilebilir:

$$
Z_{i}=\beta_{0}+\beta_{1} X_{i 1}+\beta_{2} X_{i 2}+\ldots+\beta_{m} X_{i m}
$$

Doğrusal diskriminant modellerinin taşıması gereken bazı temel ön koşullar bulunmaktadır. Bunlar aşağıdaki gibi sıralanmaktadır (Wu vd., 2008:211):

1. Bağımsız değişkenler çoklu normal dağılıma sahip olmalıdır.

2. Varyans-kovaryans matrisi homojen olmalıdır.

3. Bağımsız değişkenler arasında çoklu doğrusal bağlantı (multi-collinearity) bulunmamalıdır.

Altman geliştirdiği modelin ilk haline Z Skoru adını vermiştir. Modeldeki parametreler ve kendi örneklemine uygun olarak belirlemiş olduğu katsayılarla ${ }^{4}$ modelinin genel formu aşağıdaki gibidir:

$$
\begin{aligned}
& \mathrm{T}_{1}=\text { İşletme Sermayesi / Aktif Toplamı } \\
& \mathrm{T}_{2}=\text { Dağıtılmamış Karlar / Aktif Toplamı } \\
& \mathrm{T}_{3}=\text { Faiz ve Vergi Öncesi Kar / Aktif Toplamı } \\
& \mathrm{T}_{4}=\text { ÖzkaynaklarınPiyasa Değeri / Borç Toplamı }
\end{aligned}
$$


$\mathrm{T}_{5}=$ Net Satışlar / Aktif Toplamı

olmak üzere orijinal Z Skor modeli;

$$
Z=\left(1,2 T_{1}\right)+\left(1,4 T_{2}\right)+\left(3,3 T_{3}\right)+\left(0,6 T_{4}\right)+\left(0,999 T_{5}\right)
$$

Altman'ın Z Skor modeli, halka açık işletmelerin finansal başarısızlığını (iflasını), 22 adet finansal oran içinden seçilen 5 oran yardımıyla önceden tahmin etmek üzere geliştirilmiş ilk modeldir. Daha sonraları modelde çeşitli güncellemeler ve geliştirmelerde bulunan Altman, yeni modellere de Z' ve Z" Skor isimlerini vermiştir. Altman'ın modellerde revizyona gitmesinin nedeni ise orijinal Z Skor modelinin bağımsız değişkenlerinden olan özkaynakların piyasa değerinin, yabancı kaynakların defter değerine oranının, halka açık olmayan işletmelerin özkaynaklarının piyasa değerinin belirlenmesindeki güçlük olmuştur.

$$
\begin{aligned}
\mathrm{T}_{1} & =\text { İşletme Sermayesi / Aktif Toplamı } \\
\mathrm{T}_{2} & =\text { Dağıtılmamış Karlar / Aktif Toplamı } \\
\mathrm{T}_{3} & =\text { Faiz ve Vergi Öncesi Kar / Aktif Toplamı } \\
\mathrm{T}_{4} & =\text { ÖzkaynaklarınDefter Değeri / Borç Toplamı } \\
\mathrm{T}_{5} & =\text { Net Satışlar / Aktif Toplamı } \\
& \text { olmak üzere } \mathrm{Z}^{\prime} \text { Skor modeli; } \\
\mathrm{Z}^{\prime}= & \left(0,717 \mathrm{~T}_{1}\right)+\left(0,847 \mathrm{~T}_{2}\right)+\left(3,107 \mathrm{~T}_{3}\right)+\left(0,420 \mathrm{~T}_{4}\right)+\left(0,998 \mathrm{~T}_{5}\right)
\end{aligned}
$$

Altman modelin yeniden yapılandırılmış formunda (Z' modelinde), özkaynakların piyasa değerini değil, defter değerini kullanabilmenin önünü açmıştır. Bu model Altman tarafından yapılan bir revizyon ile yalnızca halka açık olan işletmelerin değil, halka açık olmayan işletmelerin de uygulayabilecekleri bir biçime dönüştürülmüştür. Geliştirilen yeni modele ise Altman Z' Skor modeli adı verilmiştir. Z' Skor modelinin yeniden yapılandırılması sırasında, orijinal Z Skor modelinin bağımsız değişkenlerinden olan özkaynakların piyasa değerinin, yabancı kaynakların defter değerine oranı, halka açık olmayan işletmelerin özkaynaklarının piyasa değerinin belirlenmesindeki güçlükten ötürü özkaynakların defter değerinin, yabancı kaynakların defter değerine olan oranı biçiminde değiştirilmiş̧tir.

Modelde yapılan son güncelleme ise gelişmekte olan ülke ekonomilerinde faaliyet gösteren; halka açık olan veya olmayan işletmelerin de uygulayabilecekleri bir forma geçiş imkanı sağlamıştır. Altman modelinin bu formuna da Z" Skor modeli ismini vermiştir.

$$
\begin{aligned}
& \mathrm{T}_{1}=\text { Işsletme Sermayesi / Aktif Toplamı } \\
& \mathrm{T}_{2}=\text { Dağıtılmamış Karlar / Aktif Toplamı } \\
& \mathrm{T}_{3}=\text { Faiz ve Vergi Öncesi Kar / Aktif Toplamı }
\end{aligned}
$$

$\mathrm{T}_{4}=$ Özkaynakların Defter Değeri / Borç Toplamı olmak üzere Z" Skor modeli;

$$
Z^{\prime \prime}=\left(6,56 \mathrm{~T}_{1}\right)+\left(3,26 \mathrm{~T}_{2}\right)+\left(6,72 \mathrm{~T}_{3}\right)+\left(1,05 \mathrm{~T}_{4}\right)
$$

biçiminde yapılandırılmıştır.

Altman tarafından geliştirilen Z Skor modelleri, günümüzde de akademik çalışmaların yanı sıra birçok kurum ve kuruluş tarafından piyasa gözetimi, erken uyarı, kurumsal risk ölçümü ve derecelendirme gibi amaçlar ile kullanılmaktadır (Özdemir, 2011a: 188).

\section{AMPIRIK ARAŞTIRMA}

\subsection{Araştırmanın Amacı ve Önemi}

Literatürdeki çalışmalara bakıldığında bazılarının doğrudan tahmin modellerini, bazılarının tahmin dönemi uzunluğundaki değişime bağlı olarak tahminlerin tutarlılığını karşılaştırdığı görülmektedir. Bazı çalışmalar ise, bu çalışmada olduğu gibi, modellerden ziyade başarısızlık durumları tahmin edilen işletme gruplarının niteliksel özelliklerinden kaynaklanan farklılıkların tahmin modellerinin performansı üzerindeki etkisini karşılaştırmaya odaklanmaktadır.

Örneğin Alareeni ve Branson (2012), Altman $Z$ ve $Z^{\prime \prime}$ Skor modellerinin Amerika ve Avrupa ülkelerinde olduğu gibi Ürdün'de de finansal başarısızlık tahminlerinde geçerli sonuçlar sağlayıp sağlamadığını hem sınai imalat hem de hizmet sektöründe faaliyet gösteren halka açık işletmeler yönüyle değerlendirmişlerdir. Tinoco ve Wilson (2013), 1980-2011 döneminde 23 binin üzerinde halka açık işletme üzerinden muhasebe, piyasa ve makro ekonomi tabanlı verileri bir araya getirerek kurumsal kredi riskini açıklamanın mümkün olup olmadığını bu işletmelerin finansal başarısızlık ve iflas riskini belirlemeye yönelik model geliştirmek suretiyle incelemişlerdir. Amaçları kullandıkları değişkenler çerçevesinde tutarlı tahmin imkanı sağlayan geçerli bir stres testi modeli ortaya koymak olan yazarlar, modellerinin performansını da Altman Z Skor modeli ve yapay sinir ağı modeli ile karşılaştırma yoluna gitmişlerdir.

Araştırmanın amacı ise, Altman Z' ve Z" Skor modellerinin önceki çalışmalardan farklı olarak, halka açık olan ve olmayan işletmeler yönüyle uygulanabilirliklerinin modellerin başarımları üzerinden karşılaştırmalı olarak incelemektir. Bunun için TDMS'ye dayalı finansal raporlar kullanılarak hem halka açık hem de halka açık olmayan işletmelerde bu iki modelin tutarlı açıklama güçleri belirlenmiştir.

Çalışma, önceki çalışmalardan farklı olarak, ünlü Finans Profesörü Edward Altman tarafından geliş- 
tirilmiş olan bu modelleri birbiriyle kıyaslamanın ötesinde Türkiye için bu modelleri ampirik olarak da test etme imkanı vermektedir. Şöyle ki, orijinal Z Skor modeli halka açık işletmeler için geliştirilmiş bir model özelliği taşımaktadır. Altman, halka açık olmayan işletmeler için orijinal Z Skor modelinden ayrı olarak Z' Skor modelini geliştirmiştir. Daha sonra gelişmekte olan ülke ekonomileri ve halka açık olmayan işletmeler için Z" Skor modelini ileri sürmüştür. Dolayısıyla çalışmada Türkiye'deki halka açık olan ve olmayan işletmeler için bu Z ve Z"Skor modellerini değerlendirme olanağı söz konusudur. Fakat böyle bir karşılaştırma, eğer halka açık olmayan işletmelerle, halka açık işletmeler aynı esaslar altında raporlama yapıyor ise mümkün olabilir. Türkiye'de KOBi'ler için Finansal Raporlama Standardı henüz zorunlu olarak uygulamaya sokulmadığı için bu türlü bir karşılaştırma finansal raporlama standartları temelinde yapılamamaktadır. Öte yandan TDMS her iki grup işletme için zorunlu olarak gerçekleştirilen bir raporlama sistemi olmaya devam ettiğinden TDMS'ye dayalı finansal tablo verileri kullanılarak, bu türlü bir karşılaştırma yapılmıştır.

\subsection{Araştırmanın Kapsamı}

Araştırma kapsamında, araştırmanın amacı doğrultusunda yalnızca ünlü Finans Profesörü Edward Altman tarafından geliştirilmiş Z' ve Z" Skor tahmin modelleri kullanılmıştır. Yalnızca halka açık (veyahut özkaynaklarının piyasa değerine ulaşılabilen) işletmelerce uygulanabilen Z Skor modelinin kullanılamamasının nedeni, karşılaştırmaya dayanan bu araştırmada halka açık olmayan işletmelerin de bulunmasıdır.

Finansal başarısızlığın tahmininde birinci aşama, araştırmacının finansal başarısızlığı nasıl tanımlayacağına; yani bağımlı değişkeni nasıl belirleyeceğine karar vermek olduğundan araştırmanın kapsamını mevcut veri setine uygun bir biçimde sınırlandırma gerekliliği doğmuştur. Nitekim Bemmann (2005) kullanılan verilerin kalitesi (niteliği) ile yapılacak tahminlerin başarımı arasında ilişki bulunduğunu ifade etmektedir.

Araştırma kapsamında kullanılan TDMS verilerinin özelliği gözetilerek, defter değeri esaslı bağımlı değişken seçimine gidilmiştir. Araştırmada "finansal başarısızlık" üç yıl üst üste kar edememiş olma" biçiminde tanımlanmıştır ${ }^{5}$.Esasen araştırma kapsamında Altman ve diğerleri (2007) ve Özdemir (2011a) gibi piyasa değeri esaslı tanımlamaya da gidilebilirdi. Fakat böyle bir tanımlama, TDMS verileri gibi tarihi maliyetleri değil, Uluslararası Finansal Raporlama Standartları seti gibi cari değerleri esas alan finansal raporlama sistemleri için daha uygun bir tercih olabilirdi. Piyasa değeri esaslı tanımlamalar bu nedenle araştırma kapsamı dışında tutulmuştur.
Ayrıca gerek halka açık olmayan gerekse halka açık olan işletmelerin finansal tablo verilerine ulaşmakta yaşanan güçlükler nedeniyle araştırma yalnızca 2009-2011 arasında kalan hesap dönemlerine ilişkin finansal verilere dayalı olarak gerçekleştirilmiştir.

\subsection{Araştırma Verilerinin Toplanması}

Araştırmada yaşanan güçlüklerin başında veri temininde yaşanan güçlükler gelmektedir. Nitekim bu çalışmanın verileri ne halka açık olan işletmelerin, ne de halka açık olmayan işletmelerin doğrudan kendisinden sağlanmıştır. Ülkemizde özellikle TDMS'ye dayalı finansal verileri toplama yetkisini haiz Maliye Bakanlığı da söz konusu verileri vergi mahremiyeti nedeniyle paylaşmamaktadır. Gerek halka açık işletmelerin gerekse halka açık olmayan işletmelerin bilançoları için şirketler ile doğrudan bağlantıya geçilmiş ve söz konusu finansal tabloların adi veya e-posta yoluyla gönderilmesi talep edilmiştir. Fakat alınabilen geri bildirimler yeterli sayıda finansal tablo verisine ulaşılamayacağını ortaya koymuştur. Buna istinaden defterdarlıklar, şirketlerin serbest muhasebeci mali müşavirleri ve yeminli mali müşavirleri başta olmak üzere, bağımsız denetim şirketleri, il sanayi ve ticaret müdürlükleri, kredi kuruluşları gibi çeşitli kurum veya kuruluşların yardımına başvurulmuştur.

Araştırmada halka açık statüdeki (büyük işletme niteliğindeki) 80, halka açık olmayan (görece küçük ve orta ölçekli işletme niteliğindeki) 62 sınai imalat işletmesinin verisine ulaşılabilmiş̧tir. Bu işletmelerin fiili başarısızlık tanımlamasına göre dağıımları Tablo1 'deki gibidir:

Tablo 1: Önsel Başarısızlık Tanımlamasına Göre Fiili Durumdaki Başarılı/Başarısız Gözlem Grupları

\begin{tabular}{|l|c|c|c|}
\hline & Başarılı & Başarısız & Toplam \\
\hline Halka Açık & 47 & 33 & 80 \\
\hline Halka Açık Olmayan & 40 & 22 & 62 \\
\hline
\end{tabular}

Finansal başarısızlık tahminlerinde asıl sorun yeterli sayıda başarısız gözlemin belirlenebilmesidir. Her iki grupta da belirlenen başarısız işletme sayısı literatürdeki çalışmalara bakıldığında yeterli kabul edilebilecek düzeydedir. Öte yandan araştırmanın halka açık olan ve olmayan işletme grupları yönüyle karşılaştırmayı amaçlaması bakımından da başarısız gözlemlerin toplam içindeki oranlarına bakılırsa; oranların da birbirine yakın olduğu ifade edilebilir. Nitekim halka açık işletmelerin \% 41'inin; halka açık olmayan işletmelerin ise \% $35^{\prime}$ inin önsel olarak başarısız grupta yer aldıkları kabul edilmiştir. 


\subsection{Araştırma Soruları}

Araştırma kapsamında cevabı aranan sorular aşağıdaki gibi yapılandırılmıştır:

1. Halka açık işletmeler yönüyle Z' ve Z" Skor modellerinin fiili durumu tahmindeki genel başarımları nasıldır?

2. Halka açık olmayan işletmeler yönüyle $Z^{\prime}$ ve $Z^{\prime \prime}$ Skor modellerinin fiili durumu tahmindeki genel başarımları nasıldır?

3. Halka açık işletmeler yönüyle Z' ve Z" Skor modellerinin başarısız olarak gruplandırdığı gözlemlerin birbiriyle tutarlıı̆ı̆ı nasıldır?

4. Halka açık olmayan işletmeler yönüyle $Z^{\prime}$ ve $Z^{\prime \prime}$ Skor modellerinin başarısız olarak gruplandırdığı gözlemlerin birbiriyle tutarlıığı nasıldır?

5. Türkiye gibi gelişmekte olan bir ekonomide TDMS'ye dayalı finansal veriler altında Z' ve Z" Skor modellerihalka açık olan ve olmayan işletmeler yönüyle geçerli niceliksel bir farklılık sağlıyor mu?

Araştırma sorularından ilk ikisi, halka açık olan ve olmayan işletmeler yönüyle Z' ve Z" Skor modellerinin fiili durumu tahmin etme kabiliyetlerinin karşılaştırılmasına yöneliktir.

Üçüncü ve dördüncü sorular ise halka açık olan ve olmayan işletmeler yönüyle $Z^{\prime}$ ve $Z^{\prime \prime}$ Skor modellerinin fiili duruma uygun sınıflandırma kabiliyeti dikkate alınmaksızın salt olarak birbiriyle olan tutar-
Iılığının karşılaştırılmasına yöneliktir. Bu şekilde bir karşılaştırma, halka açık olan ve olmayan işletmeler yönüyle Z' ve Z" Skor modellerinin, hem fiili başarı/ başarısızlık durumunu tahmin etme kabiliyeti dikkate alınarak hem de fiili başarı/başarısızlık durumunu tahmin etme kabiliyeti dikkate alınmaksızın ayrı ayr değerlendirme yapabilme imkânı verdiği için önem arz etmektedir.

Beşinci soru ise, dünyanın gelişmiş en büyük 10 ekonomisi arasında yer almayı hedefleyen Türkiye gibi gelişmekte olan bir ülkede, yerel (ulusal) muhasebe esaslarına göre raporlanan finansal tablo verilerini kullanarak yapılacak Altman Z' ve Z" Skor tahminlerinin halka açık olan ve olmayan işletmeler yönüyle farklılaşma gösterip göstermediğinin incelenmesine yönelik olup önceki sorulardan farklıdır. Bunun için Z ve $Z$ " modelleri nezdinde halka açık olan ve olmayan işletmeler düzeyinde yapılan tahminler değerlendirilmelidir.

\subsection{Araştırmanın Bulguları}

Araştırma neticesinde elde edilen bulgular, araştırma sorularına cevap verecek biçimde değerlendirilmiştir. Bu bağlamda ilk olarak, 1, 2 ve 3 yıl öncesinden (YÖ) Z've Z" Skor modelleri ile finansal başarısızlık tahminleri yapılmıștır. Her iki modelin fiili durumu tahmin etmedeki başarımları (performansları) ${ }^{6}$ halka açık olan ve olmayan işletmeler yönüyle ortaya konulacak biçimde aşağıdaki gibi şekiller üzerinde verilmiştir.

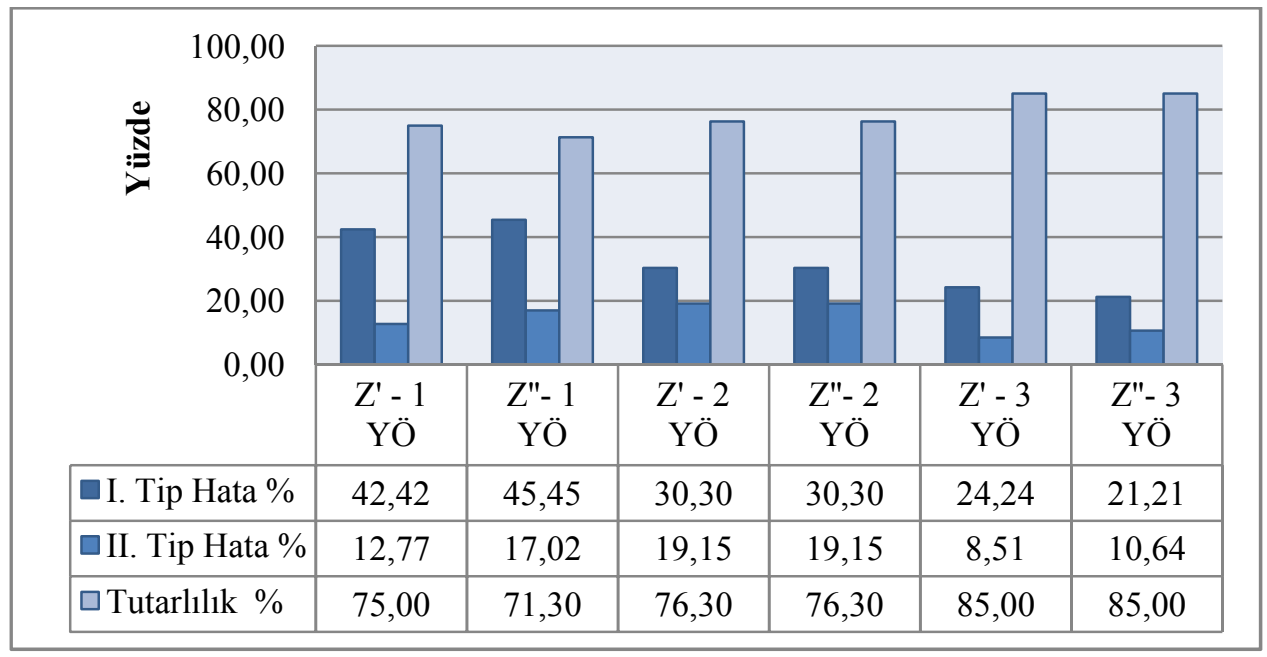

Şekil 1: Halka Açık İşletmeler Yönüyle Z’ ve Z" Skor Modellerinin Performans Değerleri

Şekil 1'de halka açık işletmeler $(n=80)$ yönüyle, Şekil 2 'de ise halka açık olmayan işletmeler $(m=62)$ yönüyle Altman Z' ve Z" Skor modellerinin başarımları sırasıyla 1, 2 ve 3 yıl öncesinden (YÖ) yapılan tahminler çerçevesinde kendi içinde değerlendirilmiştir. 


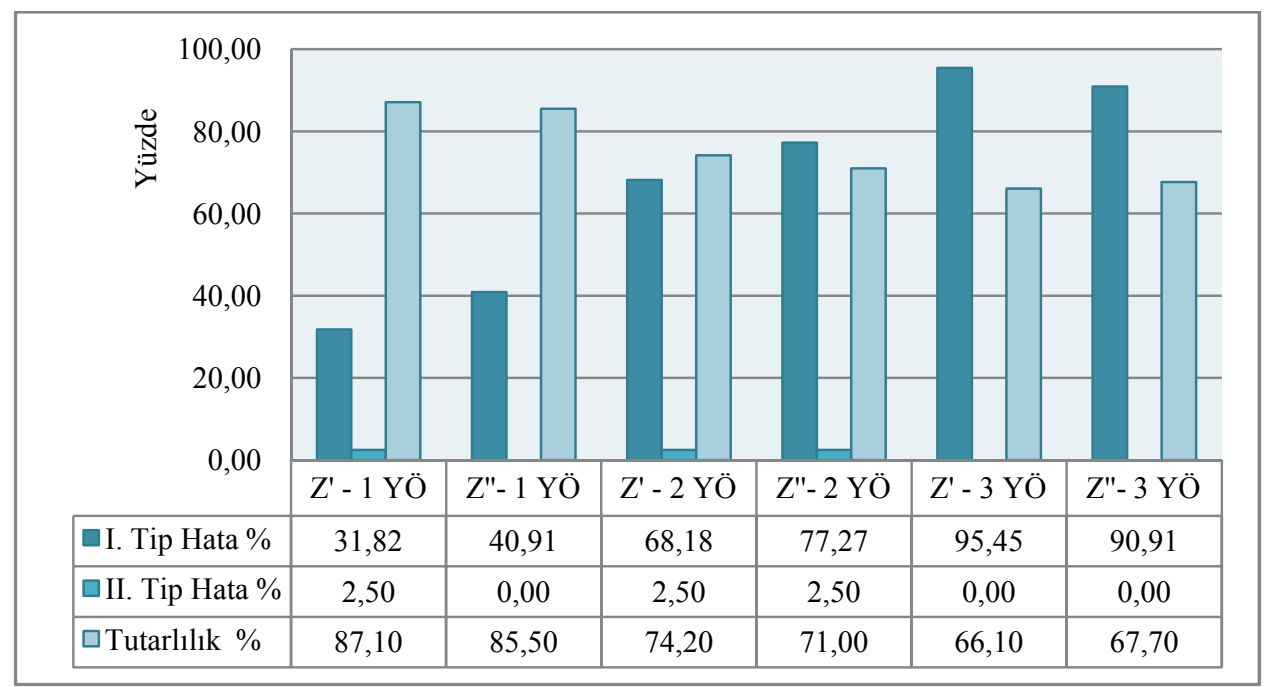

Şekil 2: Halka Açık Olmayan İşletmeler Yönüyle Z' ve Z" Skor Modellerinin Performans Değerleri

Genel olarak halka açık olan ve olmayan ișletmeler yönüyle, modellerin tutarlı sınıflandırma kabiliyeti kabul edilebilir gibi görünse de, küçük olması arzu edilen I. tip hata oranlarının (başarısız grupta sınıflandırılması gereken bir işletmenin, başarılı grupta sınıflandırılması biçimindeki hataların) yüksekliği göze çarpmaktadır. Buna karşın II. tip hata oranları ise oldukça düşük gözlenmektedir. Bu bağlamda modellerin fiili durumu tahmindeki genel başarımlarının bir yıl öncesinden yapılacak tahmin yönüyle halka açık olmayan işletmelerde, 2ve 3 yıl öncesinden yapılacak tahminler yönüyle de halka açık olan işletmelerde daha tutarlı olduğu sonucuna ulaşılmaktadır. Öyle ki, tahmin dönemi aralığının büyümesi karşısında halka açık işletmelerde I. tip ve II. tip hata oranlarının düşmesi, modellerin genel tutarlılık yüzdelerinin yükselmesine neden olmuştur. Buna karşın halka açık olmayan işletmelerde 2 ve 3 yıl öncesinden yapılan tahminlerinin yüksek I. tip hata oranlarına rağmen, genel tutarlı sınıflandırma oranlarının da yüksek olması, II. tip hata oranlarının sıfır olmasından kaynaklanmıştır.

Tahminlerin yıllar itibariyle ortaya koyduğu başarımlar yönüyle değil; $Z^{\prime}$ ve Z" Skor modellerinin birbirine göre başarımı yönüyle değerlendirme yapmayı amaçlayan bu çalışmada; halka açık işletmeler yönüyle Z' ve Z" Skor modellerinin birbirine yakın sonuçlar sağladığı; halka açık olmayan işletmelerde ise sonuçların birbirine daha da yakınlaştığı saptanmıştır. Nitekim yapılan incelemede halka açık işletmeler yönüyle Z' ve Z"Skor modellerinin 1 yıl öncesinden yapılan tahminlerde 6 gözlem ve 3 yıl öncesinden yapılan tahminlerde 2 gözlem açısından olmak üzere toplam 8 gözlemi farklı gruplarda belirledikleri tespit edilmiştir. 2 yıl öncesinden yapılan tahminler bakımından ise $Z^{\prime}$ ve $Z^{\prime \prime}$ skor modellerinin ortaya koyduğu sınıf- landırmaların bütünüyle aynı olduğu görülmüştür. Halka açık olmayan işletmeler yönüyle bakıldığında ise, Z' ve Z"Skor modellerinin 1 yıl öncesinden yapılan tahminlerde 3 gözlem, 2 yıl öncesinden yapılan tahminlerde 2 ve 3 yıl öncesinden yapılan tahminlerde 1 gözlem açısından olmak üzere toplam 6 gözlemi farkIı gruplarda belirledikleri tespit edilmiştir.

Üç farklı tahmin dönemi açısından Z' ve Z" Skor modelleri ile elde edilen sınıflandırma sonuçlarının, fiili başarı/başarısızık durumu ile olan tutarlııı̆ı dikkate alınmaksızın, salt modellerin sonuçları arasındaki tutarlılık yönüyle ölçülebilmesi amacıyla, modellerin ortaya koyduğu sınıflandırma sonuçlarının birbiriyle uyumu oranı ${ }^{7}$ biçiminde adlandırılabilecek bir orandan yararlanılabilir. Buna göre halka açık işletmelerde modellerin ortaya koyduğu sınıflandırma sonuçlarının birbiriyle uyumu oranı $\% 96,67$ 'dir $^{8}$. Halka açık olmayan işletmeler yönüyle modellerin ortaya koyduğu sınıflandırma sonuçlarının birbiriyle uyumu oranı ise $\% 96,77^{9}$ olarak belirlenmektedir.

Türkiye gibi gelişmekte olan bir ülke için Z' ve Z" Skor tahminlerinin halka açık olan ve olmayan işletmeler yönüyle farklılaşma gösterip göstermediğini ortaya koymak amaciyla da modellerin 1, 2 ve 3 yıl öncesinden tahminlerde doğru sınıflandıramadığı gözlemlerden yararlanarak sapmalı tahmin oranı ${ }^{10}$ adı verilebilecek bir orandan yararlanılabilir. 
Tablo 2: Halka Açık Olan ve Olmayan İşletmelerde Z' ve Z"Skor Tahminlerinin Birbirleriyle Uyumluluk Düzeyi

\begin{tabular}{|l|c|c|}
\hline & $\begin{array}{c}\text { Halka Açık } \\
\text { (\%) }\end{array}$ & $\begin{array}{c}\text { Halka Açık } \\
\text { Olmayan } \\
(\%)\end{array}$ \\
\hline $\begin{array}{l}\text { Z' Skor -Sapmalı Tahmin } \\
\text { Oranları }\end{array}$ & 20,42 & 24,73 \\
\hline $\begin{array}{l}\text { Z" Skor - Sapmalı Tahmin } \\
\text { Oranları }\end{array}$ & 21,67 & 25,81 \\
\hline $\begin{array}{l}\text { Z' ve Z" Skor Modelleri } \\
\text { Sınıflandırma } \\
\text { Sonuçlarının Birbiriyle Uyumu } \\
\text { Oranı }\end{array}$ & 96,67 & 96,77 \\
\hline
\end{tabular}

Tablo-2'den görüldüğü gibi, halka açık işletmeler yönüyle $Z^{\prime}$ Skor modellerinin (1, 2 ve 3 yıl öncesinden olmak üzere) sapmalı tahmin oranı \% 20,42; Z" Skor modellerinin sapmalı tahmin oranı ise \% 21,67'dir ${ }^{11}$. Buna karşın halka açık olmayan işletmeler yönüyle Z' Skor modellerinin (1, 2 ve 3 yıl öncesinden olmak üzere) sapmalı tahmin oranı \% 24,73; Z" Skor modellerinin sapmalı tahmin oranı ise $\% 25,81$ olarak belirlenmiştir ${ }^{12}$.

Sapmalı tahmin oranlarına bakarak; araştırma çerçevesinde, hem halka açık hem de halka açık olmayan işletmelerin her ikisinde de Z' Skor modellerinin, Z" modellerine göre daha tutarlı sonuçlar ortaya koyabildiği ifade edilebilir. Ancak modellerin sınıflandırma sonuçlarının birbiri ile uyumuna bakıldığında, halka açık olmayan işletmelerle, halka açık olan işletmelerin $Z^{\prime}$ ve $Z^{\prime \prime}$ model sonuçlarının birbiri ile uyumu bakımından neredeyse aynı olduğu görülmektedir. Elde edilen bu sonuçların teorideki karşılığı ise, ünlü Finans Profesörü Edward Altman'ın ileri sürdüğü ve bu çerçevede niteliksel olarak revize ettiği Z' ve Z" Skor modellerinin halka açık olan ve olmayan işletmeler açısından belirgin bir farklılığa neden olmadığının Türk sınai imalat işletmeleri yönüyle ispatlandığıdır.

\section{SONUÇ}

Araştırma sorularına bağlı olarak gerçekleştirilen analiz çerçevesinde aşağıdaki sonuçlara ulaşılmıştır:

1. Halka açık işletmeler yönüyle Z' ve Z" Skor modellerinin fiili durumu tahmindeki genel başarımları yüksek hata oranları nedeniyle düşüktür.

2. Halka açık olmayan işletmeler yönüyle $Z^{\prime}$ ve $Z^{\prime \prime}$ Skor modellerinin de fiili durumu tahmindeki genel başarımları düşüktür. Özellikle I. tip hata oranlarının halka açık olmayan işletmelerdeki göreli yüksekliği göze çarpmaktadır.

3. Z' ve Z" Skor modellerinin başarısız olarak gruplandırdığı gözlemlerin birbiriyle tutarlılığına bakıldığında halka açık işletmeler yönüyle birbirine yakın sonuçlar sağlanmaktadır. Halka açık işletmelerde mo- dellerin ortaya koyduğu sınıflandırma sonuçlarının birbiriyle uyumu oranı \% 96,67'dir.

4. Z' ve Z" Skor modellerinin başarısız olarak gruplandırdığı gözlemlerin birbiriyle tutarlılığına bakıldığında ise halka açık olmayan işletmeler yönüyle halka açık olan işletmelere nazaran birbirine $\% 0,1$ oranında daha yakın sonuçlar sağlandığı görülmektedir. Nitekim halka açık olmayan işletmeler yönüyle modellerin ortaya koyduğu sınıflandırma sonuçlarının birbiriyle uyumu oranı $\% 96,77$ olarak belirlenmektedir.

5. Son olarak, Z' ve Z" Skor modelleri halka açık olan ve olmayan işletmeler açısından niceliksel farklılık sağlamamaktadır. Bu sonuç, Altman'ın çeşitli niteliksel özellikler bakımından revize ettiği Z' ve Z" Skor modellerinin ne halka açık olan ne de olmayan Türk sınai imalat işletmeleri üzerinde yapılacak finansal başarısızlık tahminlerinde farklı bir tahmin başarımına neden olduğu anlamına gelmektedir. Bu bağlamda Z' ve Z" Skor modelleri arasında kuramsal olarak öngörülenin aksine araştırma kapsamında belirgin bir farklılık gözlenmediği ifade edilebilir.

Araştırma neticesinde ulaşılan bu sonuçlar, özetle Edward Altman tarafından ilk olarak halka açık olmayan işletmeleri, ikinci olarak da gelişmiş ülke ekonomilerinde sadece imalat sanayindeki değil, gelişmekte olan ülke ekonomilerindeki banka ve diğer finansal kuruluşlar dışında kalan tüm işletmeleri gözeterek gerçekleştirdiği model revizyonlarının, araştırmanın örneklemi üzerinde çok küçük farklıııklara neden olduğunu ortaya koymaktadır. Beklenenin aksine çarpıcı farklara ulaşılamamıştır. 


\section{SON NOTLAR}

${ }^{1} \mathrm{Bu}$ durumdaki işletmelerin acz içinde oldukları kabul edilir.

${ }^{2}$ Ayrıntılı bilgi için bakınız: Koç Yalkın, Y. (1988), s: 49-50.

${ }^{3} 1972$ ve 1977 yıllarında kademeli olarak uygulamaya konulan TDMS hakkında ayrıntılı bilgi için bakınız:

Akdoğan, N. ve Aydın, H. (1987), s: 88-89.

${ }^{4}$ Altman $\mathrm{Z}$ modelinde ve sonraki diğer modellerinde değişken olarak kullandığı oranlara ilişkin katsayı belirlerken, kendi örnekleminde dikkate aldığı gözlemlerin başarılı/başarısız olarak sınıflandırılma olasılıklarını dikkate alarak; başka bir ifadeyle kendi gözlemlerinin dinamiklerine uygun olarak belirlemede bulunmuştur. Bazı araştırmacıların, hatta internet tabanlı veri sağlayan bazı özel kuruluşların bu modelleri kullanmak istediklerinde, Altman'ın modellerini doğrudan kullanmaya kalkıştıkları görülmektedir. Oysa araştırmacıların modelde kullanılan oransal değişkenler ile diskriminant analizi yapmaları ve kendi analizleri sonucunda ulaştıkları katsayılar ile çalışmaları gerekmektedir.

5 Finansal başarısızlık tahmin modellerinde finansal başarısızlığın nasıl tanımlandığı, araştırmacının önsel kabulüdür. Ancak bazen yeterli sayıda başarısız gözleme ulaşılamadığında araştırmacıların yeterli sayıda başarısız gözlem sağlayabilecek bir araştırma dizaynı içine girmeleri gerekmektedir. Yeterli başarısız gözlem belirlemede, araştırmacıların konjonktürel olarak ekonominin iyileşme ve genişleme dönemlerinde, kötüleşme ve gerileme dönemlerine nazaran daha fazla zorlandıkları ifade edilebilir. Nitekim kimileri, yeterli gözlem sayısına erişebilmek amacıyla farklı dönemlerde gerçekleşen başarısızlık örneklerini tek bir araştırma düzleminde kabul etmekte, kimileri üç yıl üst üste zarar etmiş olma yerine iki y1l üst üste zarar etmiş olma halini tercih ederek bu güçlüğü bertaraf etmektedir. Araştırmacıların bu yola başvurmalarına olanak sağlayan en önemli husus ise amaçlarının alternatif bir başarısızlık tanımlaması geliştirmek değil; bilakis yaptıkları önsel tanımlamayı bir araç olarak kullanarak, elde ettikleri fiili başarılı/başarısız işletmelerin uyguladıkları modeller yardımıyla ne kadar tutarlı olduğunu saptamak istemeleridir.

${ }^{6}$ Finansal başarısızlık tahmin modellerinin (ya da daha genel bir ifadeyle diskiriminant modellerinin grupları ayrıştırmadaki performansı, sınıflandırma sonucunda elde edilen birinci tip hata, ikinci tip hata ve toplam tutarlı açıklama yüzdesi ölçütleri ile değerlendirilir. I. tip hata düzeyi düşük ve genel tutarlı açıklama yüzdesi ne kadar yüksek olursa, sınıflandırmanın o denli başarılı olduğu kabul edilir. Bu iki kriter bakımından eşitliğin bulunması durumunda da ikinci tip hata oranı düşük olan sınıflandırmanın daha başarılı olduğu ifade edilir. Nitekim ikinci sınıf hata, başarılı bir işletmenin modele göre başarısız olarak sınıflandırılması hatasını yansıtmaktadır.

${ }^{7}$ Araştırma sorularına cevap teşkil edecek şekilde 1, 2 ve 3 yil öncesinden yapılan tahminlerin her birinde modellerin sınıflandırma sonuçları yan yana koyulur, her bir yıl için gözlemlerin sınıflandırma sonuçları karşılaştırılarak; birbiri ile farklı olanların sayısı alınır. Sonra bu sayılar toplanır ve 3 dönem x sınıflandırılan toplam gözlem sayısına bölünür. Bulunan değer, tutarsız gözlemlerin oranını yansıtır. Tutarlı gözlemlerin oranı için bu oranın 1'den çıkarılması gerekir.

${ }^{8}$ Halka açık işletmelerde 3 tahmin döneminde tutarsızlığa sebep olan 8 gözlem dişındaki 232 gözlemin her iki modeldeki birbiriyle tutarlılığı; 8 / (3x80) = 0,0333 $\rightarrow$ $(1-0,0333)^{*} 100=\% 96,67$ şeklinde hesaplanır.

${ }^{9}$ Halka açık olmayan işletmelerde 3 tahmin döneminde tutarsızlığa sebep olan 6 gözlem dışındaki 180 gözlemin her iki modeldeki birbiriyle tutarlılığı; $6 /(3 \times 62)=$ $0,0323 \rightarrow(1-0,0323)^{*} 100=\% 96,77$ şeklinde hesaplanir.

${ }^{10}$ Sapmalı tahmin oranının belirlenmesinde; her bir modelin farklı tahmin dönemi aralıkları için fiili durumda önsel olarak başarısız olduğu tespit edildiği halde başarılı ve başarılı olarak tespit edildiği halde başarısız olarak sınıflandırdığı işletmelerin sayısı belirlenir. Bu sayı, modeldeki gözlem sayısı ile modelin kullanımı suretiyle gerçekleştirilen tahmin dönemi sayısının çarpımına bölünür. Bu oran; I. ve II. tip hata oranlarının ortalamasından farklıdır. Çünkü bu oran, modellerin yalnızca birlikte fiili durumdaki sınıflandırmadan olan sapmalarını dikkate almaktadır. Oysa I. ve II. tip hata oranlarının ortalaması alınırsa, her bir modelin bireysel olarak gösterdiği diğer sapmalar da dikkate alınmış olur.

${ }^{11}$ Halka açık işletmeler yönüyle Z' modellerinin (1, 2 ve 3 yil öncesinden yapılan tahminlerde) fiili durumdaki önsel gruplandırmadan farklı olarak sınıflandırdığı gözlemlerin oranını ifade eden sapmalı tahmin oranı; (52 / $240)^{*} 100=\% 21,67$ şeklinde hesaplanır. Z" modellerinin (1, 2 ve 3 yil öncesinden yapılan tahminlerde) fiili durumdaki önsel gruplandırmadan farklı olarak sınıflandırdığı gözlemlerin oranını ifade eden sapmalı tahmin oranı ise; $(49 / 240) * 100=\%$ 20,42 şeklinde hesaplanır.

${ }^{12}$ Halka açık olmayan işletmeler yönüyle Z' modellerinin (1, 2 ve 3 yıl öncesinden yapılan tahminlerde) fiili durumdaki önsel gruplandırmadan farklı olarak sınıflandırdığ oranı; $(46 / 186)^{*} 100=\% 24,73$ şeklinde hesaplanır. Z" modellerinin (1, 2 ve 3 yıl öncesinden yapılan tahminlerde) fiili durumdaki önsel gruplandırmadan farklı olarak sınıflandırdığı gözlemlerin oranını ifade eden sapmalı tahmin oranı ise; $(48 / 186) * 100=\% 25,81$ şeklinde hesaplanır. 


\section{KAYNAKLAR}

Akdoğan, N. ve Aydın, H. (1987) Muhasebe Teorileri,Ankara, Ankara Üniversitesi Basımevi.

Akdoğan, N. ve Sevilengül, O. (2007) Türkiye Muhasebe Standartlar ile Uyumlu Tekdüzen Muhasebe Sistemi Uygulaması, 13. Baskı, İstanbul, İSMMMO.

Aktaş, R. (1991) "Endüstri İsletmeleri İçin Mali Başarısızlık Tahmini (Çok Boyutlu Model Uygulaması)'Yayınlanmamış Doktora Tezi, Ankara, Ankara Üniversitesi Sosyal Bilimler Enstitüsü.

Aktaş, R. (1993)Endüstri İsletmeleri İçin Mali Başarısızlık Tahmini (Çok Boyutlu Model Uygulaması), Ankara, Türkiye İş Bankası Kültür Yayınları.

Aktaş, R. (1997) Mali Başarısızlık (İsletme Riski) Tahmin Modelleri, 2.Baskı, Ankara, Türkiye İş Bankası Kültür Yayınları.

Alareeni, B. ve Branson, J. (2013) "Predicting Listed Companies' Failure in Jordan Using Altman Models: A Case Study" International Journal of Business and Management, 8(1):113-126.

Altman, E.I. (1968) "Financial Ratios, Discriminant Analysis and the Prediction of Corporate Bankruptcy" The Journal of Finance 23(4):589-609.

Altman, E.I., Sabato, G. ve Wilson, N. (2010) "The Value of Non-Financial Information in Small and Medium-Sized Enterprise Risk Management" The Journal of Credit Risk,6(2):1-33.

Altman, E. I., Zhang, L. ve Yen, J. (2007) Corporate Financial Distress Diagnosis in China, New York University Salomon Center Working Paper.

Beaver, W.H. (1966) "Financial Ratios as Predictors of Failure" Journal of Accounting Research, 71-111.

Bemmann, M. (2005) Improving the Comparability of Insolvency Predictions, Dresden University of Technology, Faculty of Business Management and Economics, Working Report No:8

Casey, C. ve Bartczak, N. (1985) "Using Operating Cash Flow Data to Predict Financial Distress: Some Extensions" Journal of Acconting Research 23(1):384-401.

Choi, F.D.S. ve Meek, G.K. (2008) International Accounting, $6^{\text {th }}$ Edition, New Jersey, Pearson Prentice Hall.

Doğrul, Ü. (2009) “Finansal Başarısızlık ve Finansal Başarısızlığın Tahmini: Hisse Senetleri İstanbul Menkul Kıymetler Borsasında İşlem Gören Sınai İşletmeler Üzerinde Bir Uygulama” Yayınlanmamış Yüksek Lisans Tezi, Mersin, Mersin Üniversitesi Sosyal Bilimler Enstitüsü.
Elam, R. (1975) "The Effect of Lease Data on the Predictive Ability of Financial Ratios" The Accounting Review 50(1):25-43.

Göktan, E. (1981) "Muhasebe Oranları Yardımıyla ve Diskriminant Analiz Tekniği Kullanarak Endüstri İşletmelerinin Mali Başarısızlığının Tahmini Üzerine Ampirik Bir Araştırma” Yayınlanmamış Doçentlik Tezi, Ankara.

Hiçşaşmaz, M. (1970) Muhasebenin Teorisi ve Teknik Yapısı,Ankara, Ankara İktisadi ve Ticari İlimler Akademisi Yayını.

Kartal, A. (2005) Maliyet Muhasebesi, Eskişehir, Anadolu Üniversitesi Yayını.

Keskin, Y. (2002) "İşletmelerde Finansal Başarısızlığın Tahmini, Çok Boyutlu Model Önerisi ve Uygulaması” Yayınlanmamış Doktora Tezi, Ankara, Hacettepe Üniversitesi Sosyal Bilimler Enstitüsü.

Koç Yalkın, Y. (1972) “Tekdüzen Muhasebe Sistemi” Ankara Üniversitesi Siyasal Bilgiler Dergisi, 27:971-990.

Koç Yalkın, Y. (1988) İşletmelerde Mali Analiz Teknikleri,6. Baskı, Ankara, Siyasal Bilgiler Fakültesi.

Kurtaran, Ç.M. (2009) "Finansal Başarısızlık Tahmin Modellerinin İMKB,deki Firmalar İçin Karşılaştırmalı Analizi” Yayınlanmamış Doktora Tezi, Trabzon, Karadeniz Teknik Üniversitesi Sosyal Bilimler Enstitüsü.

Miller, W. (2009) "Introducing the Morningstar Solvency Score, A Bankruptcy Prediction Metric” http:// ssrn.com/abstract=1516762, (13.04.2013).

Ohlson, J.A. (1980) "Financial Ratios and the Probabilistic Prediction of Bankruptcy" Journal of Accounting Research, 18(1):109-131.

Özdemir, F.S. (2011a) "Finansal Raporlama Sistemlerinin Bilginin İhtiyaca Uygunluğu Açısından Değerlendirilmesi: İMKB Şirketlerinde Finansal Başarısızlık Tahminleri Yönüyle Bir Uygulama” Yayınlanmış Doktora Tezi.

Özdemir, F.S. (2011b) Finansal Başarısızlık ve Finansal Tablolara Dayalı Tahmin Yöntemleri, Ankara, Siyasal Kitabevi.

Özdemir, F.S., Choi, D.S.F., Bayazıtl1, E. (2012) "Finansal Başarısızlık Tahminleri Yönüyle UFRS ve Bilginin İhtiyaca Uygunluğu, Mali Çözüm Dergisi, 22:17-52.

Ross, S.A., Westerfield, R. W. ve Jaffe, J. (2002) Corporate Finance,6. Bask1, Irwin, McGraw-Hill.

Tinoco, M.H.veWilson, N. (2013) “Financial Distress and Bankruptcy Prediction Among Listed Companies Using Accounting, Market and Macroeconomic Variables" International Review of Financial Analysis, 29:1-26. 
Yılgör, A.G., Doğrul, Ü. ve Orekici, T.G. (2011) "A New Approach to Predict Financial Failure: Classification and Regression Trees (CART)" Journal of Modern Accounting and Auditing 7(4):329-339.

Zavgren, C.V. (1982) "A Logistic Analysis of the Relationship Between Vulnerability to Failure and
Certain Financial Variables for American Industrial Firms" Purdue University, Krannert Graduate School of Management Working Report.

Zmijewsjki, M.E.(1984) "Essay on Corporate Bankruptcy" Unpublished Ph.D Dissertation, Buffalo, State University of New York. 


\section{EKLER}

Ek 1A: 1 Yıl Öncesinden Yapılan Tahmin Modellerinin Sınıflandırma Sonuçları

\begin{tabular}{|c|l|c|c|c|}
\hline \multicolumn{5}{|c|}{ Halka Açık İşletmeler Yönüyle Z' Skor Modeli } \\
\hline \multirow{2}{*}{ Sayı } & Başarısız & Başarılı & Toplam \\
\cline { 2 - 5 } & Başarısız & 19 & 14 & 33 \\
\hline \multirow{2}{*}{$\%$} & Başarılı & 6 & 41 & 47 \\
\cline { 2 - 5 } & Başarırııı & 57,58 & 42,42 & 100 \\
\hline
\end{tabular}

(Not: $75,0 \%$ of original grouped cases correctly classified.)

\begin{tabular}{|c|l|c|c|c|}
\hline \multicolumn{5}{|c|}{ Halka Açık İşletmeler Yönüyle Z" Skor Modeli } \\
\hline \multirow{2}{*}{ Sayı } & Başarısız & Başarılı & Toplam \\
\cline { 2 - 5 } & Başarısız & 18 & 15 & 33 \\
\cline { 2 - 5 } & Başarıı & 8 & 39 & 47 \\
\hline \multirow{2}{*}{$\%$} & Başarısız & 54,55 & 45,45 & 100 \\
\cline { 2 - 5 } & Başarılı & 17,02 & 82,98 & 100 \\
\hline
\end{tabular}

(Not: $71,3 \%$ of original grouped cases correctly classified.)

\begin{tabular}{|c|l|c|c|c|}
\hline \multicolumn{5}{|c|}{ Halka Açık Olmayan İsletmeler Yönüyle Z' Skor Modeli } \\
\hline \multirow{2}{*}{ Sayı } & Başarısıı & Başarılı & Toplam \\
\cline { 2 - 5 } & Başarılı & 15 & 7 & 22 \\
\hline \multirow{2}{*}{$\%$} & Başarısız & 1 & 39 & 40 \\
\cline { 2 - 5 } & Başarılı & 2,50 & 97,50 & 100 \\
\hline
\end{tabular}

(Not: $87,1 \%$ of original grouped cases correctly classified.)

\begin{tabular}{|c|l|c|c|c|}
\hline \multicolumn{5}{|c|}{ Halka Açık Olmayan İşletmeler Yönüyle Z" Skor Modeli } \\
\hline \multirow{2}{*}{ Sayı } & Başarısız & Başarılı & Toplam \\
\cline { 2 - 5 } & Başarısıı & 13 & 9 & 22 \\
\hline \multirow{2}{*}{$\%$} & Başarısız & 0 & 40 & 40 \\
\cline { 2 - 5 } & Başarıı & 0,00 & 100,00 & 100 \\
\hline (Not: 85,5\% of original grouped cases correctly classified.) \\
\hline
\end{tabular}

Ek 1 B: 2 Yıl Öncesinden Yapılan Tahmin Modellerinin Sınıflandırma Sonuçları

\begin{tabular}{|c|l|c|c|c|}
\hline \multicolumn{5}{|c|}{ Halka Açık Işletmeler Yönüyle Z' Skor Modeli } \\
\hline \multirow{2}{*}{} & Başarısız & Başarılı & Toplam \\
\hline \multirow{2}{*}{ Sayı } & Başarısız & 23 & 10 & 33 \\
\cline { 2 - 5 } & Başarııı & 9 & 38 & 47 \\
\hline \multirow{2}{*}{$\%$} & Başarııız & 69,70 & 30,30 & 100 \\
\cline { 2 - 5 } & Başarııı & 19,15 & 80,85 & 100 \\
\hline
\end{tabular}

(Not: $76,3 \%$ of original grouped cases correctly classified.)

\begin{tabular}{|c|l|c|c|c|}
\hline \multicolumn{5}{|c|}{ Halka Açık İşletmeler Yönüyle Z" Skor Modeli } \\
\hline \multirow{2}{*}{ Sayı } & Başarısız & Başarılı & Toplam \\
\cline { 2 - 5 } & Başarısız & 23 & 10 & 33 \\
\cline { 2 - 5 } & Başarılı & 9 & 38 & 47 \\
\hline \multirow{2}{*}{$\%$} & Başarısız & 69,70 & 30,30 & 100 \\
\cline { 2 - 5 } & Başarılı & 19,15 & 80,85 & 100 \\
\hline
\end{tabular}

(Not: $76,3 \%$ of original grouped cases correctly classified.)

\begin{tabular}{|c|l|c|c|c|}
\hline \multicolumn{5}{|c|}{ Halka Açık Olmayan İşletmeler Yönüyle Z' Skor Modeli } \\
\hline \multirow{2}{*}{ Sayı } & Başarısız & Başarıı & Toplam \\
\hline \multirow{2}{*}{$\%$} & Başarısız & 7 & 15 & 22 \\
\cline { 2 - 5 } & Başarııı & 1 & 39 & 40 \\
\hline \multirow{2}{*}{$\%$} & Başarısız & 31,82 & 68,18 & 100 \\
\cline { 2 - 5 } & Başarııı & 2,50 & 97,50 & 100 \\
\hline
\end{tabular}

(Not: $74,2 \%$ of original grouped cases correctly classified.)

\begin{tabular}{|c|l|c|c|c|}
\hline \multicolumn{5}{|c|}{ Halka Açık Olmayan Işsletmeler Yönüyle Z" Skor Modeli } \\
\hline \multirow{2}{*}{ Sayı } & Başarısız & Başarılı & Toplam \\
\cline { 2 - 5 } & Başarısız & 5 & 17 & 22 \\
\hline \multirow{2}{*}{$\%$} & Başarırııı & 1 & 39 & 40 \\
\cline { 2 - 5 } & Başarılı & 22,73 & 77,27 & 100 \\
\hline \multirow{2}{*}{ (Not: 71,0\% of original grouped cases correctly classified.) } \\
\hline
\end{tabular}


Ek 1.C: 3 Yıl Öncesinden Yapılan Tahmin Modellerinin Sınıflandırma Sonuçları

\begin{tabular}{|c|c|c|c|c|}
\hline \multicolumn{5}{|c|}{ Halka Açık İşletmeler Yönüyle Z' Skor Modeli } \\
\hline & & Başarısız & Başarılı & Toplam \\
\hline \multirow{2}{*}{ Sayı } & Başarısız & 25 & 8 & 33 \\
\hline & Başarılı & 4 & 43 & 47 \\
\hline \multirow{2}{*}{$\%$} & Başarısız & 75,76 & 24,24 & 100 \\
\hline & Başarılı & 8,51 & 91,49 & 100 \\
\hline \multicolumn{5}{|c|}{ (Not: $85,0 \%$ of original grouped cases correctly classified. } \\
\hline \multicolumn{5}{|c|}{ Halka Açık İşletmeler Yönüyle Z" Skor Modeli } \\
\hline & & Başarısız & Başarılı & Toplam \\
\hline \multirow{2}{*}{ Sayı } & Başarısız & 26 & 7 & 33 \\
\hline & Başarılı & 5 & 42 & 47 \\
\hline \multirow{2}{*}{$\%$} & Başarısız & 78,79 & 21,21 & 100 \\
\hline & Başarılı & 10,64 & 89,36 & 100 \\
\hline \multicolumn{5}{|c|}{ (Not: $85,0 \%$ of original grouped cases correctly classified. } \\
\hline \multicolumn{5}{|c|}{ Halka Açık Olmayan İşletmeler Yönüyle Z' Skor Modeli } \\
\hline & & Başarısız & Başarılı & Toplam \\
\hline \multirow{2}{*}{ Sayı } & Başarısız & 1 & 21 & 22 \\
\hline & Başarılı & 0 & 40 & 40 \\
\hline \multirow{2}{*}{$\%$} & Başarısız & 4,55 & 95,45 & 100 \\
\hline & Başarılı & 0,00 & 100,00 & 100 \\
\hline \multicolumn{5}{|c|}{ (Not: $66,1 \%$ of original grouped cases correctly classified.) } \\
\hline \multicolumn{5}{|c|}{ Halka Açık Olmayan İşletmeler Yönüyle Z" Skor Modeli } \\
\hline & & Başarısız & Başarılı & Toplam \\
\hline \multirow{2}{*}{ Sayı } & Başarısız & 2 & 20 & 22 \\
\hline & Başarılı & 0 & 40 & 40 \\
\hline \multirow{2}{*}{$\%$} & Başarısız & 9,09 & 90,91 & 100 \\
\hline & Başarılı & 0,00 & 100,00 & 100 \\
\hline
\end{tabular}


